\title{
The Study of Border Regional Health by Using The Concept of Health Indonesia Programs With Family Approach (PIS-PK)(Case Study in Purwantoro District, Wonogiri Regency 2017)
}

\author{
Tri Puji Kurniawan \\ Universitas Veteran Bangun Nusantara \\ Sukoharjo, Indonesia \\ tripujisiip@gmail.com
}

\begin{abstract}
At 2016, in Purwantoro Community Health Center area, based on the reports from the MCH Program Manager, there were 10 deaths from 468 live births. Purwantoro (a part of Wonogiri) when is compared to the achievement target, it appears that the ratio for general practitioner and dentist has not reached the target. The ratio pharmacy personnel per 100,000 population is still far from what is expected because until 2014 the ratio of pharmaceutical workers has only reached 5 per 100,000 population (IS 2010 target is 100 per 100,000 populations). The type of this research is analytic observational with cross sectional research design. Health Center Work Area of Purwantoro and Health Center of Puh Pelem. The survey techniques are used Rapid Survey Method. The populations in this research were all households in the Puh Pelem Health Center and Purwantoro Community Health Center such as 1. This sampling technique used a survey of " $30 \times 7$ ", the selection of 30 clusters in probability proportionate to size (PPS) sample size of 210 kk. Result: Purwantoro District IKS $=76 / 105=$ 0.723,. Puh Sub district IKS Pelem $=96 / 105=0.914$. There is a relationshipbetween JKN card ownership with the Healthy Family Index in Purwantoro District, there is a relationship between the availability of clean water facilities and the Healthy Family Index in Puwantoro district. Suggestion: the government is re-collecting and realizing Equity for JKN membership in the border area of Wonogiri Regency, Realizing the entry of PDAMs to villages on the border of Wonogri district and providing access to healthy latrines through community empowerment programs (latrines arisan) especially in Purwantoro District.
\end{abstract}

Keywords - availability of clean water facilities and healty family index, JKN, KS indicators (healty family)

\section{INTRODUCTION}

The Millennium Development Goals (MDGs) require certain achievements in 2015 , so this is a target as well as a challenge that must be achieved by the country in 2015 . These targets are lowered to the provincial level, which is then passed on to the district and city levels. The importance of achieving the MDGs is indicated by the issuance of Instruksi Presiden No 3 Tahun 2010 about the Equitable Development Programs, which mention that policy makers take the necessary steps in accordance with their respective duties, functions and authorities, in the context of implementing equitable development programs, one of which is the program of Achieving Goals Millennium Development. In the MDGs, there are 8 (eight) main objectives, of which 5 (five) of them relate both directly and indirectly to the health sector.

In line with MDGs and Instruksi Presiden No 3 Tahun 2010, the Government of Wonogiri District issued as a District Head Regulation No. 9 of 2012 concerning of the Minimum Service Standards (SPM) in the Health Sector of Wonogiri, mandating the achievement of the 2015 Minimum Service Standard based on the targets contained in Peraturan Menteri Kesehatan (Permenkes) No. 741 / MENKES / PER / VII / 2008 about Minimum Service Standards for Health in District/Cities.

The need for information in the community, from day to day shows a clear improvement. It is coupled with the technological support that allows of information to be accessed in a very short time. People are increasingly critical of health problems, especially if this is their needs and problems, their needs for information will be increasingly felt. This pubic concern provides positive values for the development of health development, so that the demands of data and information that are wellpackaged, simple, informative, and timely can be available.

Thus it is clear that the aim of the Health Profile is to provide a means for planning, monitoring, and evaluating the achievements of health development in the working area of the Health Centers which refers to the Wonogiri Regent's Vision, namely the Realization of a Credible and Effective Wonogiri Government for the Creation of a Quality and Virtuous Community Life Your Majesty, Free from Poverty, as well as guidance and supervision of assisted health centers in achieving District Vision.

In order to implement the Healthy Indonesia Program, the Ministry of Health has published the General Guidelines for the Healthy Indonesia Program with a Family Approach. The guidelines state that the leading implementers of the Healthy Indonesia Program with Family Approach are Community Health Centers (Puskesmas). Therefore, the publication of the General Guidelines for the Healthy Indonesia Program with the Family Approach must immediately be followed by the issuance of technical guideline. According to Peraturan Menteri Kesehatan Nomor 75 Tahun 2014 concerning Community Health Centers, it is health service facilities that conduct public heath efforts (SMEs) and first-level individual health efforts (UKP), by prioritizing promote and preventive efforts to achieve community health at the highest level in its working area. Health Center is responsible for one area of the 
government administration, namely sub-district or part of the sub-district. Peraturan Menteri Kesehatan No. 75 tahun 2014 also confirms the following two functions of Health Centers, they are: 1 . the implementation of first-level SMEs, namely activities to maintain and improve health and prevent and overcome to the emergence of health problems targeting families, groups and communities.

The importance of the family approach is also mandated in the Ministry of Health Strategic Plan at 2015/2019. In the Strategic Plan, it is stated that one of the references to the Ministry of Health's policy direction is the adoption of an integrated and sustainable health care approach. It means that health services must be carried out on all stages of the human life cycle, from being in the womb, to being born into a baby, growing to being a toddler, school-age child, teenager, productive age, and finally becoming elderly or elderly adults to be able to carry out sustainable health services to all stages of the human life cycle, the focus of health services must be on families. The provision of health services to individuals must be seen and treated as part of their families.

\section{RESEARCH METHODOLOGY}

This research used analytic observational with cross sectional research design, a study that analyze the correlation dynamics between risk factors and effect, by means of approach, observation or data collection at the same time (point time approach). This survey technique is known as rapid survey method. The time and place of this research in the Working Area of Purwantoro Health Center and Puh Pelem Health Center was conducted on 2 to 28 October 2017. The populations in this research were all households in the Health Centers of Puh Pelem and Purwantoro Health Centers 1 sampling technique. This simple survey is used a " $30 \times 7$ " survey ( $\mathrm{MOH}, 1998)$ sample size of 210. Questioner is used in reviewing Public Health analysis refers to the Regulation of the Minister of Health the Republic Indonesia Number 39 of 2016 about Guidelines for Implementing a Healthy Indonesia Program with Family Approach. In the framework of conducting the survey, this guideline including 12 main indicators as a marker of a family's health status.

\section{RESULT AND DISCUSSION}

\section{A. Relationship between JKN card ownership and Healthy} Family Index in Puh Pelem District

Based on the analysis of JKN card ownership relationship with the Healthy Family Index in Puh Pelem Subdistrict using the chi square test, the results are as shown in the following table.

Based on the Table 1, it can be seen that households $(K K)$ who have the JKN cards with a healthy family category are $4.7 \%$, whereas those who have a JKN card with an unhealthy family category are $1.9 \%$. KK who do not have a JKN card with a healthy family category are $41.9 \%$ while those who do not have a JKN card are categorized as healthy pre-family $19.1 \%$. The results of the statistical test with the chi-square method with a confidence level of $95 \%$ or $\alpha: 0.05$ obtained the value of $\rho$ value: 0,021 which means that there is a JKN card ownership relationship with the Healthy Family Index in Puh Pelem District.

TABLE 1 RELATIONSHIP BETWEEN JKN CARD OWNERSHIP AND HEALTHY FAMILY INDEX

\begin{tabular}{lccc}
\hline JKN card & Family Healthy Index & Amontl & Prosentase
\end{tabular}
owner

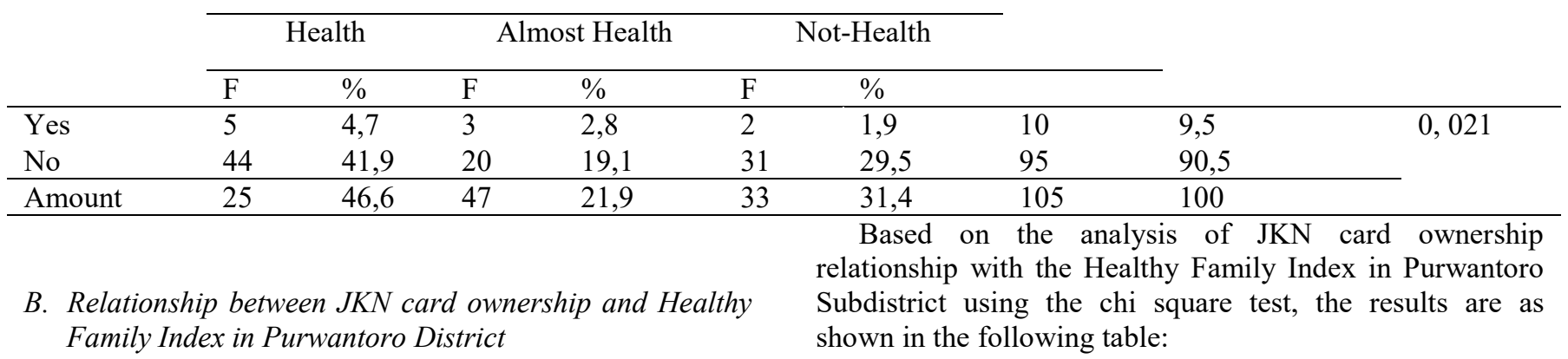

TABLE 2 RELATIONSHIP BETWEEN JKN CARD OWNERSHIP AND THE HEALTHY FAMILY INDEX

\begin{tabular}{|c|c|c|c|c|c|c|c|c|c|c|}
\hline \multirow{3}{*}{$\begin{array}{l}J K N \\
\text { card }\end{array}$} & \multirow[t]{3}{*}{ owner } & \multicolumn{6}{|c|}{ Family Healthy Index } & \multirow[t]{3}{*}{ Amount } & \multirow[t]{3}{*}{ Prosentase } & \multirow[t]{3}{*}{$\rho$ value } \\
\hline & & \multicolumn{2}{|c|}{ Health } & \multicolumn{2}{|c|}{ Almost Health } & \multicolumn{2}{|c|}{ Not-Health } & & & \\
\hline & & $\mathrm{F}$ & $\%$ & $\mathrm{f}$ & $\%$ & $\mathrm{~F}$ & $\%$ & & & \\
\hline Yes & & 10 & 9,5 & 22 & 21 & 18 & 17,1 & 50 & 47,6 & 0,000 \\
\hline No & & 12 & 11,5 & 20 & 19 & 23 & 21,9 & 55 & 52,4 & \\
\hline Amour & & 22 & 21 & 42 & 40 & 41 & 39 & 105 & 100 & \\
\hline
\end{tabular}


According to Peraturan Presiden No. 12 tahun 2013 article 43. Puh Pelem District IKS $=96 / 105=0.914$ so that Puh Pelem Subdistrict is called Kecamatan with Healthy Families and Purwantoro District IKS $=76 / 105=0.723$, so Purwantoro Sub-district is called Kecamatan with PreHealthy Families. a survey of $9.5 \%$ is a very small number compared to the one that has a JKN card of $90.5 \%$. Whereas for Purwantoro Subdistrict almost equal to $\mathrm{KK}$ who have JKN cards and who do not have JKN, which has $47.6 \%$ and who do not have $52.4 \%$.

The participation of the community to become JKN members cannot be separated from the amount of income earned every certain period of time, because the community must spend their own money to pay dues every month. A high economic level will make someone think of choosing good health services too. On the other hand, someone with low income will think several times in determining the type of contribution or class of service chosen, especially when the contribution is increased, it can burden the community even though health insurance is important. Previous research Desi Rohmawati (2014) shows that there is a relationship between socio-economic (income) and JKN Mandiri membership, especially related to the selection of types of JKN Mandiri participant contributions with $\rho$ value $=0,000$.

Communication in this case is related to information received about BPJS. This relates to information received and knowledge of respondents and the decision of respondents in choosing to participate in JKN membership. There are many sources to get information, both from the officers themselves such as through social, media from word of mouth, or print or electronic media. The ability to get this information is closely related to education. The lack or lack of education taken can cause the limited ability of respondents to access information such as internet use. The better the information obtained, the better the perception of someone to decide whether to participate in JKN.

Perceptions about the benefits of financing guarantees from JKN providers encourage one to take precautions, one of which is the decision to choose membership independently. The existence of trust in perceived benefits or obstacles will create a perception. The perception of high benefits and low perception of barriers allows one to register for JKN participants. If the perception of benefits to the program is high, it will encourage behavior change in the desired direction.

C. Relationship between the availability of clean water facilities and the Healthy Family Index in Purwantoro District

Based on the results of the analysis of the relationship between the availability of clean water facilities and the Healthy Family Index in Purwantoro Subdistrict using the chi square test statistical results obtained in the following table.

TABLE 3 RELATIONSHIP BETWEEN THE AVAILABILITY OF CLEAN WATER FACILITIES AND THE HEALTHY FAMILY INDEX

\begin{tabular}{lccc}
\hline $\begin{array}{l}\text { Hyginie } \\
\text { Water }\end{array}$ & Family Healthy Index & Amount & Prosentase
\end{tabular}

\begin{tabular}{|c|c|c|c|c|c|c|c|c|c|}
\hline & \multicolumn{2}{|c|}{ Health } & \multicolumn{2}{|c|}{ Almost Health } & \multicolumn{2}{|c|}{ Not-Health } & & & \\
\hline & $\mathrm{F}$ & $\%$ & $\mathrm{f}$ & $\%$ & $\mathrm{~F}$ & $\%$ & & & \\
\hline Available & 24 & 22,9 & 15 & 14,3 & 8 & 7,6 & 47 & 44,8 & 0,011 \\
\hline $\begin{array}{l}\text { Not- } \\
\text { Available }\end{array}$ & 12 & 11,4 & 11 & 10,5 & 35 & 33,3 & 58 & 55,2 & \\
\hline Amount & 36 & 34,3 & 26 & 24,8 & 43 & 40,9 & 105 & 100 & \\
\hline
\end{tabular}

Based on Table 3, it can be seen that households (KK) that have clean water availability in the healthy family category are $22.9 \%$, while those who have clean water availability are in the unhealthy family category of $7.6 \%$. HHs that are not provided with clean water in the healthy family category are $11.4 \%$ while KK who do not have clean water with an unhealthy family category $33.3 \%$. Statistical test results with chi-square method with a $95 \%$ or $\alpha$ : 0.05 confidence level obtained the value of $\rho$ value: 0,011 which means that there is a relationship between the availability of clean water facilities and the Healthy Family Index in Purwantoro District.

Based on KK survey, Purwantoro District IKS = 76/105 $=0.723$, so Purwantoro District is called Kecamatan with Pre-Healthy Families. KKs who have clean water availability in the healthy family category are $22.9 \%$, while that households that have clean water availability are in the unhealthy family category $7.6 \%$. HHs that are not provided with clean water in the healthy family category are $11.4 \%$ while KK who do not have clean water with an unhealthy family category $33.3 \%$. The percentage of those who have clean water availability is $44.8 \%$ and those who do not have as much as $55.2 \%$. The well owned in one of the villages in Purwantoro sub-district is used in comparison to 1 well used or taken by water at 10 households. Access to PDAM has not entered of the area.

In Act No. 23 of 1992 concerning of health in Article 22 paragraph 23 , it is stated that the water sanitation includes of safeguarding and stipulating water quality for various needs of human life. Water sanitation efforts the aim to ensure the availability of drinking water or clean water that meets health requirements for all urban and rural communities. To ensure the availability of water quality that meets these requirements, various efforts have been carried out by the government and the community, such as the construction and improvement of clean water / drinking water facilities, water quality monitoring efforts and counseling on health relations with the availability of water that meets health requirements. clean water quality standards namely Permenkes R.I No.416 / MENKES / PER / $I X / 1990$ and drinking water quality standards namely Permenkes R.I. No.492 / MENKES / PER / IV / 2010. In Peraturan Menteri Kesehatan Republik Indonesia No. 492 / 
MENKES / PER / IX / 2010 concerning to the requirements of drinking water can be seen from the physical, chemical, biological and radioactive parameters contained in the drinking water.

\section{Relation of the availability of healthy family latrines} with the Healthy Family Index in Purwantoro District

Based on the analysis of the relationship between the availability of family healthy latrines and the Healthy Family Index in Purwantoro Subdistrict using the chi square test statistical results obtained in the following Table 4.

Based on Table 4, it can be seen that households that have healthy family latrines with healthy pre-family category are $4.8 \%$, whereas those who have healthy family latrines with unhealthy family categories are 8.6\%. Households with no healthy latrines for families with healthy family categories were $2.9 \%$ while families with no healthy latrines for families with unhealthy family categories were $40.9 \%$. The results of the statistical test with the chi-square method with a $95 \%$ or $\alpha$ : 0.05 confidence level obtained the value of $\rho$ value: 0 , which means that there is a relationship between the availability of family healthy latrines with the Healthy Family Index in Purwantoro District.

TABLE 4 THE RELATIONSHIP BETWEEN HEALTHY FAMILY LATRINES AVAILABILITY AND HEALTHY FAMILY INDEX

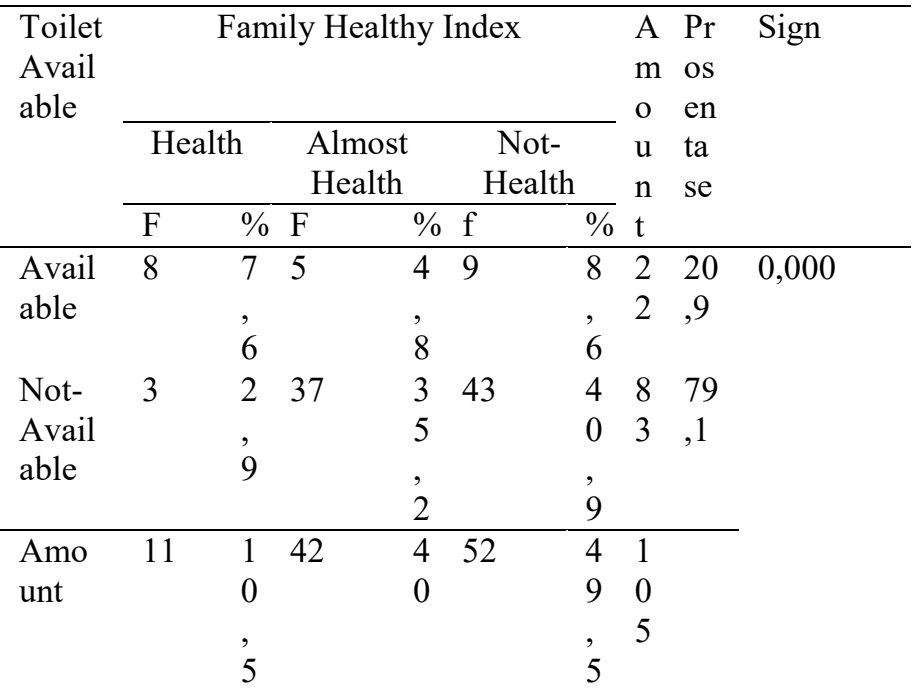

The Housholds $(K K)$ who have the availability of healthy family latrines with a healthy pre-family category $4.8 \%$, whereas that families who have a healthy latrine family availability with an unhealthy family category are $8.6 \%$. Households with no healthy latrines for families with healthy family categories were $2.9 \%$ while families with no healthy latrines for families with unhealthy family categories were $40.9 \%$. The percentage that has the availability of family healthy latrines is $20.9 \%$ and $79.1 \%$ of those who do not have a family healthy latrine.
BABS habits are more caused because they feel more comfortable and free when defecating in the river. Because the tai immediately disappeared along with the river water flow. In addition, the characteristics of people who feel unable to defecate if the buttocks do not come into contact with water. Respondents' knowledge about latrines as much as $96 \%$ knows the function and type of healthy latrines. While $60 \%$ of those who understand the disease caused by BABS habits. The level of education is low so that the livelihoods are mostly farmers. So the habit of BABS in the river as well as to look for rocks to get additional income.

The results of the study indicate that the limitations of toilet facilities in the household encourage the behavior of BABS. Low economic income results in family latrine problems not the top priority that must be provided. This is supported by the quality of latrines in the community as much as $20.9 \%$ utilizing healthy latrines, which require higher financing for its manufacture if compared to the toilet latrine. Besides that, the toilet is not a toilet that is chosen. Geographical conditions that are mostly passed by the river and there are still many open areas also support BABS behavior.

\section{CONCLUSION}

1) Purwantoro District IKS $=76 / 105=0.723$, so Purwantoro District is called District with Pre-Healthy Families.

2) Puh Pelem District IKS $=96 / 105=0.914$ so that Puh Pelem Subdistrict is called District with Healthy Families.

3) There is an ownership relationship of the JKN card with the Healthy Family Index in the Puh Pelem District

4) There is an ownership relationship of the JKN card with the Healthy Family Index in Purwantoro District,

5) There is a relationship between the availability of clean water facilities and the Healthy Family Index in Purwantoro District.

6) there is a relationship between the availability of family healthy latrines with the Healthy Family Index in Purwantoro District.

\section{ACKNOWLEDGMENT}

1. The government is re-collecting and realizing Equity for the member of JKN in the border area of Wonogiri Regency

2. Fulfillment of the availability of facilities and infrastructure for health services for health centers, especially Puh Pelem health centers, to be used as a 24-hour inpatient health center, as well as evaluating health services in Purwantoro sub-district.

3. The Community Health Center carries out community empowerment, especially in vulnerable groups for the form of Elderly Posyandu

4. Exchange of health workers and health cadres between regions at the border periodically

5. Realizing the entry of $P D A M \mathrm{~s}$ to villages on the border of Wonogiri district

6. Perform environmental health programs especially to make ODF villages in all villages in the Wonogiri district border 
7. Providing access to healthy latrines through community empowerment programs (latrines arisan), especially in Purwantoro District

8. Improving the water supply for clean water channels in the village of Puh Pelem District

\section{REFERENCES}

[1] Arikunto, S.. Prosedur Penelitian Suatu Pendekatan Praktek, Jakarta : Rineka Cipta, Edisi Ketiga. 1996

[2] Balai Pustaka.. Kamus Besar bahasa Indonesia. Tim Penyusun Kamus Pusat Pembinaan Dan pengembangan Bahasa.Jakarta. 1990.

[3] Depkes RI. Modul Pelatihan Stop Buang AirBesar Sembarangan (STOP BABS), Ditjen PP danPL bekerjasama dengan Pokja AMPL Pusat. Jakarta. 2008.

[4] Depkes RI, Rencana Pembangunan jangka Panjang Bidang Kesehatan. 2005-2025, Jakarta. 2009.

[5] Dinas Kesehatan Kabupaten Wonogiri. Sosialisasi/ Workshop Community Led Total Sanitation (CLTS) / Sanitasi total Berbasis Masyarakat. Wonogiri. 2008.

[6] Ditjen PP dan PL. Pedoman PelaksanaanSanitasi Total Berbasis Masyarakat (STBM). Depkes RI: Jakarta. 2011.

[7] Desy Rohmawati. Hubungan Pengetahuan Sikap Dan Sosial Ekonomi Dengan Pemilihan Jenis Iuran Keikutsertaan JKN Mandiri Pada Wilayah Cakupan JKN Tertinggi Di Surakarta. Skripsi. Surakarta. Universitas Muhammadiyah Surakarta. 2014.

[8] DINKES Provinsi Jateng. Pelaksanaan Jaminan Kesehatan Nasional Oleh BPJS Kesehatan Bulan Januari 2014. Semarang : Dinas Kesehatan Provinsi Jawa Tengah. 2014.

[9] Keputusan Menteri Kesehatan Republik Indonesia (Kemenkes RI) No. 852/Menkes/SK/IX/2008 tentang Sanitasi Total Berbasis Masyarakat (STBM). Jakarta.

[10] Kementerian Sekretaris Negara RI. Peraturan Pemerintah RI No 38 tahun 2011 tentang Sungai, Jakarta. 2011.

[11] Kartono. Perilaku Manusia. ISBN : Jakarta. 2006.

[12] KEMENKES RI. Modul Penelitian Jaminan Kesehatan bagi Petugas Puskesmas. Jakarta : Kementerian Kesehatan RI. 2012.

[13] Laporan Akses Kemajuan Jamban Kabupaten Wonogiri. Akses KemajuanJamban Bulan Nopember2015. Dinas Kesehatan Kabupaten Wonogiri. 2015.

[14] Nancy I. Sihombing, Hubungan Karakteristik Dan Persepsi Masyarakat Tentang Jaminan Kesehatan Nasional (JKN) Terhadap Keikutsertaan Menjadi Peserta JKN Di Kota Medan Tahun 2014. Skripsi. Medan. Universitas Sumatera Utara. 2014.

[15] Notoadmodjo, Soekidjo, Pendidikan dan Perilaku Kesehatan .Rineka Cipta: Jakarta. 2003.

[16] Notoadmodjo, Soekidjo, Kesehatan Masyarakat Ilmu Dan Seni. Rineka Cipta. Jakarta. 2011.

[17] Notoatmodjo, Soekidjo. Promosi Kesehatan dan Perilaku Kesehatan. Rineka Cipta: Jakarta. 2012.

[18] Peraturan Bupati Wonogiri, Tentang Sanitasi Total Berbasis Masyarakat.Wonogiri. 2015.

[19] Peraturan Menteri Kesehatan No 3 Tahun 2014 tentang Sanitasi Total Berbasis Masyarakat. Jakarta.

[20] Peraturan Presiden No 12 Tahun 2013 tentang Jaminan Kesehatan (Lembaran Negara Republik Indonesia Tahun 2013 Nomor 29). 2013. Jakarta : Kementerian Komunikasi dan Informasi Republik Indonesia

[21] Peraturan Presiden No 28 Tahun 2016 tentang Perubahan Ketiga Atas Peraturan Presiden No 12 Tahun 2013 tentang Jaminan Kesehatan. Jakarta : Kementerian Komunikasi dan Informasi Republik Indonesia. 2016.

[22] Sugiyono, Statistik Untuk Penelitian. CV Alfabeta. Bandung. 1999.

[23] WSP - EAP ( Water And Sanitasion ProgramEast Asia And The Pacifik). Informasi Pilihan Jamban Sehat. Jakarta. 2011 